GRASAS Y ACEITES 67 (3)

July-September 2016, e144

ISSN-L: 0017-3495

doi: http://dx.doi.org/10.3989/gya.1017153

\title{
Wheat germ oil extracted by supercritical carbon dioxide with ethanol: Fatty acid composition
}

\author{
B. Parczewska-Plesnar ${ }^{\mathrm{a}, \bigotimes}$, R. Brzozowski ${ }^{\mathrm{b}}, \mathrm{H}$. Gwardiak ${ }^{\mathrm{b}}$, E. Białecka-Florjańczyk ${ }^{\mathrm{a}}$ and Z. Bujnowski ${ }^{\mathrm{b}}$ \\ ${ }^{a}$ Department of Chemistry, Faculty of Food Sciences, Warsaw University of Life Sciences, \\ Nowoursynowska 159c, 02-776 Warszawa, Poland. \\ ${ }^{\mathrm{b}}$ Industrial Chemistry Research Institute, Rydygiera 8, 01-793 Warsaw, Poland. \\ ${ }^{\square}$ Corresponding author: bozena_parczewska_plesnar@sggw.pl
}

Submitted: 14 October2015; Accepted: 04 April 2016

SUMMARY: In this work, supercritical fluid extraction (SFE) using $\mathrm{CO}_{2}$ with ethanol as entrainer was performed at a temperature of $40{ }^{\circ} \mathrm{C}$ under a pressure of $21 \mathrm{MPa}$. For comparison, a similar extraction without the entrainer was carried out. The extraction yield of wheat germ using supercritical $\mathrm{CO}_{2}$ with ethanol was slightly higher $(10.7 \mathrm{wt} \%)$ than that of extraction without the entrainer $(9.9 \mathrm{wt} \%)$. Fractions of SFE extracts were collected separately during the experiments and the composition of fatty acids in each fraction was analyzed. The SFE extracted oils were rich $(63.4-71.3 \%)$ in the most valuable polyunsaturated fatty acids (PUFA) and their content in all collected fractions was approximately constant. Similar PUFA contents were found in the reference samples of oils extracted by $n$-hexane $(66.2-67.0 \%)$, while the commercial cold-pressed oil contained significantly less PUFA (60.2\%). These results show a higher nutritional value of the oil obtained by extraction with supercritical $\mathrm{CO}_{2}$ than cold pressed oil which is generally considered to be very valuable.

KEYWORDS: Entrainer; Extraction; Polyunsaturated fatty acids; Supercritical $\mathrm{CO}_{2}$; Wheat germ oil

RESUMEN: Aceite de germen de trigo obtenido mediante extracción con dióxido de carbono supercrítico con etanol: Composición en ácidos grasos. En este trabajo, la extracción con fluidos supercríticos (SFE) usando $\mathrm{CO}_{2}$ con etanol como agente de arrastre se realizó a $40{ }^{\circ} \mathrm{C}$ bajo una presión de $21 \mathrm{MPa}$. Se ha llevado a cabo la comparación con una extracción similar sin agente de arrastre. El rendimiento de la extracción de germen de trigo usando $\mathrm{CO}_{2}$ supercrítico con etanol fue ligeramente mayor (10,7\% en peso) que la de extracción sin agente de arrastre $(9,9 \%$ en peso). Se recogieron por separado fracciones de extractos SFE durante los experimentos y se analizó la composición de ácidos grasos en cada fracción. Los aceites extraídos mediante SFE eran ricos en los ácidos grasos poliinsaturados más valiosos $(63,4-71,3 \%$ ), (PUFA) y su contenido en todas las fracciones recogidas fue aproximadamente constante. Un contenido similar de PUFA fueron encontrados en muestras de referencia de los aceites extraídos con n-hexano (66,2-67,0\%), mientras que el aceite prensado en frío comercial contenía significativamente menos PUFA (60,2\%). Estos resultados muestran un mayor valor nutritivo del aceite obtenido por extracción con $\mathrm{CO}_{2}$ supercrítico que el aceite prensado en frío que generalmente se considera que es muy valioso.

PALABRAS CLAVE: Aceite de germen de trigo; $\mathrm{CO}_{2}$ supercrítico; Entrainer; Extracción de ácidos grasos poliinsaturados

Citation/Cómo citar este artículo: Parczewska-Plesnar B, Brzozowski R, Gwardiak H, Białecka-Florjańczyk E, Bujnowski Z. 2016. Wheat germ oil extracted by supercritical carbon dioxide with ethanol: Fatty acid composition. Grasas Aceites, 67 (3): e144. doi: http://dx.doi.org/10.3989/gya.1017153.

Copyright: (C) 2016 CSIC. This is an open-access article distributed under the terms of the Creative Commons Attribution-Non Commercial (by-nc) Spain 3.0 Licence. 


\section{INTRODUCTION}

Wheat is one of the most common cereal crops. However, it is generally consumed as white flour obtained from the endosperm which constitutes about $85 \%$ of the grain. The endosperm does not contain the highest nutritional value and consists mainly of starch and storage proteins. A relatively small portion of the grain, called the germ, which accounts for about $2-3 \%$ of its volume, contains $26 \%$ protein, $17 \%$ sugar and about $10 \%$ oil rich in valuable unsaturated fatty acids (Wang and Johnson, 2001; Durante et al., 2012). Wheat germ is one of the richest natural sources of vitamin E. It also contains vitamin B and many micronutrients. This valuable part of the grain is mostly treated as a by-product in the production of flour and is used as animal feed. Only a portion of it is sold as an ingredient for human diets in health food stores. A small amount is subjected to cold-pressing or extraction in order to recover oils rich in nutrient components. This high-quality oil is used for example as a component of food, pharmaceutical or cosmetic preparations.

Cold-pressing is a very old, but still common method of producing high quality oil. An advantage of pressed oil is the lack of chemical contaminants, which is a prerequisite for its application as a component of healthy food. Unfortunately, the efficiency of this method is low in comparison with others and garners about $50 \%$ of total oil content in wheat germ (Panfili et al., 2003). Solvent extraction using a Soxhlet apparatus is much more effective than pressing and enables producers to recover about $90 \%$ of the total oil. Its efficiency depends on the type of solvent used. The most commonly applied solvent is $n$-hexane, but the use of petroleum ether, chloroform and ethanol have also been investigated (Dunford et al., 2003; Piras et al., 2009). Besides extraction under normal pressure, a pressurized solvent extraction has also been studied (Dunford et al., 2003). Another method that extracts the wheat germ oil of similar quality is aqueous enzymatic extraction $(\mathrm{Li}$ et al., 2011; Xie et al., 2011).

Supercritical extraction with $\mathrm{CO}_{2}$ is, perhaps, the most promising method which combines the advantages of both methods mentioned above. Supercritical extraction of wheat germ has been intensively studied in recent years. The effect of factors such as pressure, temperature, $\mathrm{CO}_{2}$ flow, particle size and moisture content in the feed on the extraction efficiency was studied. Durante et al. (2012) found that the optimal conditions for the best oil yield were: pressure $30-35 \mathrm{MPa}$, temperature $60-70{ }^{\circ} \mathrm{C}$, moisture content $2.6 \%$, particle size 30 mesh (particles smaller than $0.595 \mathrm{~mm}$ ) and a $\mathrm{CO}_{2}$ flow rate of $4 \mathrm{dm}^{3} \cdot \mathrm{min}^{-1}$. Panfili et al. (2003) estimated that the best performance used a pressure of $38 \mathrm{MPa}$, temperature $55^{\circ} \mathrm{C}$, the particle size of
$0.35 \mathrm{~mm}$ and a $\mathrm{CO}_{2}$ flow equal to $1.5 \mathrm{dm}^{3} \cdot \mathrm{min}^{-1}$. In contrast, the optimal conditions determined by Gomez et al. (2000) differed from the previous ones and were as follows: $15 \mathrm{MPa}, 40{ }^{\circ} \mathrm{C}$ and $1.5 \mathrm{dm}^{3} \cdot \mathrm{min}^{-1}$ of $\mathrm{CO}_{2}$. According to Jiang et al. (2011) a maximum oil yield of $10.46 \%$ was achieved when the particle size was $60-80$ mesh $(0.170$ $0.250 \mathrm{~mm}$ ), water content $4.37 \%$, pressure $30 \mathrm{MPa}$, temperature $40{ }^{\circ} \mathrm{C}$ and $\mathrm{CO}_{2}$ flow rate $20 \mathrm{~kg} \cdot \mathrm{h}^{-1}$. Optimizing the efficiency of extraction at a flow rate of $2 \mathrm{~g} \cdot \mathrm{min}^{-1}$, Gelmez et al. (2009) determined the following conditions: $44.2 \mathrm{MPa}, 40{ }^{\circ} \mathrm{C}$. However, in order to obtain a higher content of tocopherols and greater antioxidant capacity, it is better to use the following conditions: $14.8-16.5 \mathrm{MPa}, 40-60{ }^{\circ} \mathrm{C}$. According to Ge et al. (2002) the most favourable conditions for the maximum efficiency of extraction of vitamin E were $26.2 \mathrm{MPa}$ and 40 or $45^{\circ} \mathrm{C}$. Similar temperature and pressure $\left(40^{\circ} \mathrm{C}\right.$ and $\left.25 \mathrm{MPa}\right)$ were used by Özcan et al. (2013).

Summarising the results of the cited works, the temperature does not significantly affect the efficiency of extraction and a temperature of about $40^{\circ} \mathrm{C}$ is the most often recommended. The increase in pressure improves the yield, but lower pressures of 14.8-26.2 MPa should be used to increase the content of valuable components in the extract.

Supercritical extraction is often used for extracting oil from seeds. The most common non-polar solvent is $\mathrm{CO}_{2}$, but sometimes small amounts of a polar entrainer are added to enrich the extracted oil in polar nutrients (King et al., 2001; Salgin, 2007; Salgin et al., 2011; Jozwiak et al., 2013). However, we did not find reports describing wheat germ supercritical extraction using $\mathrm{CO}_{2}$ with the addition of an entrainer in the literature.

The aim of this work was to study the extraction of wheat germ oil using supercritical $\mathrm{CO}_{2}$ with addition of ethanol, as a safe polar entrainer and to compare the result with a similar extraction without entrainer and with a conventional solvent extraction. Extract fractions were collected separately during the course of the experiments and their composition was analyzed to determine the content of various fatty acids. Whether the use of an entrainer affects the fatty acid profile in the total extract and subsequent fractions was investigated.

\section{MATERIALS AND METHODS}

\subsection{Materials}

Two kinds of germ produced from wheat grown in Poland were used for extraction. The first was the wheat germ offered by the Kupiec company (Poland), commercially available in stores and intended for direct consumption. The second raw material was the wheat germ received directly from a local mill in Ciechanowiec (Poland). 
The moisture in wheat germ feeds was determined using Moisture Analyzers (Radwag MAC 50/NH) and amounted to $8.06 \%$ and $8.26 \%$, respectively.

The comparative sample was the cold-pressed wheat germ oil, purchased from the company LOGIS-TECH (Mirków, Poland) and the sample was denoted as CPO.

\subsection{Extraction methods}

The wheat germ samples from the Kupiec company and from the Ciechanowiec mill were tested in extraction with supercritical $\mathrm{CO}_{2}$ with the addition of ethanol as entrainer. For comparison wheat germ from the Kupiec company was extracted without entrainer. Each extraction was carried out using the wheat germ without grinding.

The scheme of the test unit for supercritical extraction is shown in Figure 1. The volume of the extractor was $150 \mathrm{~cm}^{3}$, and that of separators about $50 \mathrm{~cm}^{3}$. Details of the apparatus have been described elsewhere (Jozwiak et al., 2013, Bujnowski et al., 2011). A pressure of $21 \mathrm{MPa}$ and temperature of $40{ }^{\circ} \mathrm{C}$ were selected as standard conditions of SFE experiments. The average flow rate of $\mathrm{CO}_{2}$ was about $60 \mathrm{dm}^{3} \cdot \mathrm{h}^{-1}$ (at ambient pressure).

Prior to the extractions with entrainer, $10 \mathrm{~cm}^{3}$ of ethanol was added directly to the germ, and then $2 \mathrm{~cm}^{3} \cdot \mathrm{h}^{-1}$ of ethanol were fed simultaneously with $\mathrm{CO}_{2}$ to the extractor. Fractions of the extract were collected every 6 hours ( 3 hours for extraction without ethanol) or if the amount of the extract was too small, time for collection was prolonged to ensure an adequate amount of oil for analysis purposes. In the case of extraction of wheat germ from the Kupiec company, the temperature of the last fraction was increased to $60{ }^{\circ} \mathrm{C}$ in order to monitor whether such a temperature increase improved the yield. Samples of extracts obtained by supercritical extraction of

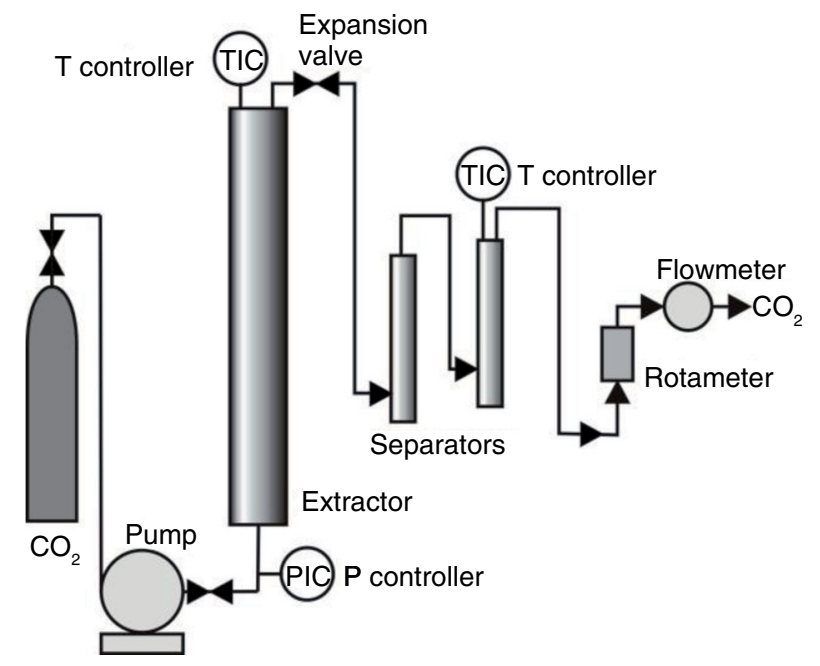

FIGURE 1. Scheme of apparatus for supercritical extraction tests. wheat germ from the Kupiec company with and without ethanol entrainer were denoted as SFE-KE and SFE-K, respectively, and extract samples obtained by the supercritical $\mathrm{CO}_{2}$ extraction with ethanol of the feed from the mill were denoted as SFE-ME.

For comparison with the SFE extracts, extractions of both types of wheat germ were also performed using a Soxhlet apparatus with $n$-hexane (POCh, 95\%, for HPLC) as solvent and the samples were denoted as SE-KH and SE-MH, respectively. Extractions for each of the two types of germ were carried out twice and both extracts were combined. For a single extraction, about $70 \mathrm{~g}$ of wheat germ and $450 \mathrm{~cm}^{3}$ of $n$-hexane were used. The extraction was carried out for $8 \mathrm{~h}$.

\subsection{Analytical method}

Fatty acids composition analysis was performed after derivatization to form the methyl esters using the AOCS Ce 1-62 method (American Oil Chemists' Society, 1989). Methyl esters of long-chain fatty acids were prepared according to AOCS Ce 2-66 method (American Oil Chemists' Society, 1989). A GC7890A gas chromatograph with a flame ionization detector (FID) (Agilent Technologies) was used. The chromatograph was equipped with a SUPELCOWAX 10 capillary column 30 m length, $0.32 \mathrm{~mm}$ internal diameter, $0.25 \mu \mathrm{m}$ film thickness. The chromatographic conditions were: detector temperature of $260{ }^{\circ} \mathrm{C}$, injector temperature of $250{ }^{\circ} \mathrm{C}$, volume injected of $1 \mu \mathrm{L}$, the carrier gas was helium with a flow rate of $1 \mathrm{ml} / \mathrm{min}$ and split flow ratio 50:1. The oven temperature programme was set as follows: $200-260{ }^{\circ} \mathrm{C}\left(4{ }^{\circ} \mathrm{C} \cdot \mathrm{min}^{-1}\right), 260{ }^{\circ} \mathrm{C}$ (10 min). Uncertainty of fatty acid content determination, expressed by relative standard deviation (RSD) depends on fatty acid content:

- $\quad \mathrm{RSD}=1.3 \%$ for contents higher than $40 \%$,

- $\quad$ RSD $=3.0 \%$ for contents higher than 10 and lower than $40 \%$,

- $\quad$ RSD $=5.9 \%$ for contents higher than 1 and lower than $10 \%$,

- $\quad \mathrm{RSD}=11.3 \%$ for contents lower than $1 \%$.

Fatty acids were identified using a GC/MS analysis with the help of Wiley 9th Edition / NIST 2009 Mass Spectral Library and by comparing the GC retention times of the peaks with the retention times of standards.

\section{RESULTS AND DISCUSSION}

\subsection{Extraction yield}

The conditions of supercritical extraction and amounts of obtained fractions of oil extracts are listed in Table 1. In each of the three SFE extractions, 
TABLE 1. The results of wheat germ extraction using supercritical CO2 without (SFE-K) and with ethanol (SFE-KE and SFE-ME) carried out at $40{ }^{\circ} \mathrm{C}$ under pressure of $21 \mathrm{MPa}$

\begin{tabular}{|c|c|c|c|c|}
\hline & $\begin{array}{l}\text { Fraction } \\
\text { number }\end{array}$ & $\begin{array}{c}\text { Extraction time of } \\
\text { subsequent fraction (h) }\end{array}$ & $\begin{array}{l}\text { solvent/feed amount } \\
\text { ratio }\left(\mathrm{dm}^{3} \cdot \mathrm{g}^{-1}\right)\end{array}$ & $\begin{array}{l}\text { Mass of oil } \\
\text { fraction }(\mathrm{g})\end{array}$ \\
\hline \multirow{10}{*}{$\begin{array}{l}\text { SFE-K } \\
\text { (wheat germ produced by Kupiec, feed } \\
\text { amount } 90.98 \mathrm{~g} \text {, average flow rate of } \mathrm{CO}_{2} \\
\text { at ambient pressure } 63.0 \mathrm{dm}^{3} \cdot \mathrm{h}^{-1} \text { ) }\end{array}$} & 1 & 3 & 2.1 & 2.4004 \\
\hline & 2 & 3 & 4.1 & 1.95225 \\
\hline & 3 & 3 & 6.2 & 1.4024 \\
\hline & 4 & 3 & 8.3 & 1.2671 \\
\hline & 5 & 3 & 10.4 & 0.97075 \\
\hline & 6 & 3 & 12.4 & 0.49205 \\
\hline & 7 & 3 & 14.5 & 0.18505 \\
\hline & 8 & 5.5 & 18.3 & 0.19015 \\
\hline & 9 & 3 & 20.4 & 0.0894 \\
\hline & $10^{*}$ & 3 & 22.5 & 0.0577 \\
\hline \multirow{5}{*}{$\begin{array}{l}\text { SFE-KE } \\
\text { (wheat germ produced by Kupiec, feed } \\
\text { amount } 94.8 \mathrm{~g} \text {, average flow rate of } \mathrm{CO}_{2} \\
\text { at ambient pressure } 58.4 \mathrm{dm}^{3} \cdot \mathrm{h}^{-1} \text { ) }\end{array}$} & 1 & 6 & 3.7 & 6.2024 \\
\hline & 2 & 6 & 7.4 & 2.9740 \\
\hline & 3 & 6 & 11.1 & 0.8093 \\
\hline & 4 & 12 & 18.5 & 0.1260 \\
\hline & $5^{*}$ & 6 & 22.2 & 0.0619 \\
\hline \multirow{5}{*}{$\begin{array}{l}\text { SFE-ME } \\
\text { (wheat germ produced at the } \\
\text { Ciechanowiec mill, feed amount } 109.6 \\
\text { g, average flow rate of } \mathrm{CO}_{2} \text { at ambient } \\
\text { pressure } 63.1 \mathrm{dm}^{3} \cdot \mathrm{h}^{-1} \text { ) }\end{array}$} & 1 & 6 & 3.5 & 5.7353 \\
\hline & 2 & 6 & 6.9 & 2.7456 \\
\hline & 3 & 6 & 10.4 & 1.8323 \\
\hline & 4 & 6 & 13.8 & 0.5109 \\
\hline & 5 & 18 & 24.2 & 0.2414 \\
\hline
\end{tabular}

"The temperature of collecting this fraction was increased to $60^{\circ} \mathrm{C}$ in order to check whether such a temperature increase improved the yield.

the first fractions were the largest but subsequently decreased with time. In order to check whether the increase in temperature increased the efficiency of extraction, the last fractions in both extractions of wheat germ from Kupiec were collected at a temperature raised to $60^{\circ} \mathrm{C}$. However, there was no visible change.

Figure 2 shows the dependence of the total yield of the three SFE extractions on solvent/feed amount ratio. As seen in the graph, the addition of ethanol to $\mathrm{CO}_{2}$ slightly improved the efficiency of extraction. In the extraction without entrainer (SFE-K), a yield of $9.9 \mathrm{wt} \%$ was achieved, and smaller amounts of extracts were collected, therefore a long time, i.e. over $32 \mathrm{~h}$ was necessary to extract all the extractable components. In the supercritical extraction of wheat germ from the Kupiec company with the addition of entrainer (SFE-KE) the yield reached $10.7 \mathrm{wt} \%$, which was a little higher than the yield of $9.9 \mathrm{wt} \%$ in the extraction without ethanol (SFE$\mathrm{K})$. In the case of SFE-ME extraction, the yield was about $10.1 \mathrm{wt} \%$, which was a little lower than in a similar extraction of wheat germ from Kupiec. The difference in yields may be due to differences in the

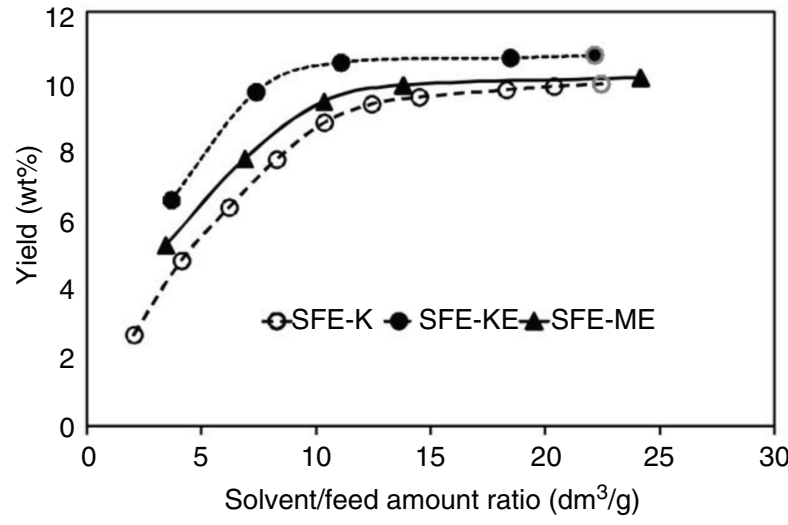

FIGURE 2. The effect of solvent/feed amount ratio on the yield of supercritical extraction of wheat germ using $\mathrm{CO}_{2}$ (SFE-K) and $\mathrm{CO}_{2}$ with ethanol (SFE-KE and SFE-ME).

amount of extractable components or moisture contents of the raw materials.

Comparative samples of wheat germ from the Kupiec company and from the Ciechnowiec mill, extracted using $n$-hexane, achieved a yield of 
Wheat germ oil extracted by supercritical carbon dioxide with ethanol: Fatty acid composition $\bullet 5$

TABLE 2. The percentage contents of PUFA, MUFA and SFA groups of fatty acids in wheat germ oils obtained by different methods of extraction (SFE-K, SFE-KE, SFE-ME, SE-KH and SE-MH) and cold-pressing method (CPO)

\begin{tabular}{|c|c|c|c|c|c|c|c|c|c|}
\hline \multirow[b]{3}{*}{$\begin{array}{l}\text { Group of } \\
\text { fatty acids }\end{array}$} & \multicolumn{9}{|c|}{ Type of wheat germ and extraction method } \\
\hline & \multicolumn{2}{|c|}{ SFE-K } & \multicolumn{2}{|c|}{ SFE-KE } & \multicolumn{2}{|c|}{ SFE-ME } & \multirow[b]{2}{*}{ SE-KH } & \multirow[b]{2}{*}{ SE-MH } & \multirow[b]{2}{*}{$\mathrm{CPO}$} \\
\hline & $\begin{array}{l}\text { Content } \\
\text { range in } \\
\text { fractions }\end{array}$ & $\begin{array}{c}\text { Content } \\
\text { in overall } \\
\text { extract }\end{array}$ & $\begin{array}{l}\text { Content } \\
\text { range in } \\
\text { fractions }\end{array}$ & $\begin{array}{c}\text { Content } \\
\text { in overall } \\
\text { extract }\end{array}$ & $\begin{array}{l}\text { Content } \\
\text { range in } \\
\text { fractions }\end{array}$ & $\begin{array}{c}\text { Content } \\
\text { in overall } \\
\text { extract }\end{array}$ & & & \\
\hline PUFA & $63.6-68.6$ & 66.1 & $65.4-72.1$ & 66.8 & $64.4-65.9$ & 65.5 & 67.2 & 66.3 & 61.6 \\
\hline MUFA & $13.1-17.7$ & 14.2 & $9.3-20.0$ & 14.0 & $13.7-20.9$ & 15.4 & 14.0 & 15.1 & 21.5 \\
\hline SFA & $14.5-22.7$ & 19.2 & $13.8-20.5$ & 18.8 & $12.9-20.5$ & 18.4 & 18.8 & 18.4 & 16.8 \\
\hline
\end{tabular}

$11.3 \mathrm{wt} \%$ and $10.7 \mathrm{wt} \%$, respectively, and the tendency was similar to the supercritical extraction. Total yields of extracts observed in both the solution and supercritical extraction were slightly higher or similar to those reported in the literature (Gomez et al., 2000; Jiang et al., 2011).

\subsection{Fatty acid composition}

For all oil fractions obtained by supercritical extractions, $n$-hexane extractions and cold-pressed oils, the fatty acid compositions were determined. This allowed us to check whether the fatty acid composition changed during the extraction and whether use of ethanol as an entrainer affected their composition. The nutritional value of fats is greater if the content of polyunsaturated fatty acids (PUFA) is higher. The presence of monounsaturated fatty acids (MUFA) is also profitable, while saturated fatty acids (SFA) have the lowest value. The concentrations of the above mentioned groups of acids in wheat germ oil obtained by different methods of extraction and the cold-pressing method are summarized in Table 2. The results show that the addition of ethanol to the supercritical $\mathrm{CO}_{2}$ did not affect the fatty acid composition of the whole collected extract (SFE-K compared with SFE-KE). It can also be noted that the total concentrations of the three groups of fatty acids in the extracted oil were similar to those obtained by other investigators (Gomez et al., 2000; Jiang et al., 2011; Özcan et al., 2013; Eisenmenger and Dunford, 2008).

The collected wheat germ oils are characterized by a high content of PUFA in all fractions, varying from 63.6 to $72.1 \%$. Similar values of $66.3-67.2 \%$ were observed for oils extracted by $n$-hexane, but a little lower value of $61.6 \%$ for cold-pressed oil. The contents of various PUFA in subsequent fractions of oils corresponding to the values of solvent volume to feed mass ratios are shown in Figure 3. The major polyunsaturated acid was linoleic acid (C18:2). Its content was very similar in all fractions of oils obtained using supercritical extraction methods, regardless of whether $\mathrm{CO}_{2}$ was used with the addition of ethanol or alone. This content ranged from 54.2 to $60.6 \%$. Similar values were found in the oils extracted with $n$-hexane from the germ produced by Kupiec, the germ from the Ciechanowiec mill and cold-pressed oil, which were 57.8, 58.0 and $55.0 \%$, respectively.

The second polyunsaturated acid with the highest content in the oil was linolenic acid (C18:3) and as in the case of linoleic acid, its content was practically the same in subsequent oil fractions obtained from the supercritical extraction. There were some differences between the three extractions, but they were smaller than the estimated detection error. In the case of SFE-K extraction, these contents in all fractions were $8.7-9.3 \%$, and for SFE-KE extraction they were $8.4-11.3 \%$. However, in the SFE-ME extraction the contents of linolenic acid were lower varying in the range of $7.9-8.4 \%$. Comparable linolenic acid contents were found in the oils extracted with $n$-hexane, i.e. 9.2 and $8.2 \%$ for germ from the Kupiec company and from the Ciechanowiec mill, respectively. A slightly lower content of this acid, i.e. $6.5 \%$, was determined for the cold-pressed oil.

Eicosadienoic acid (C20:2) and heptadienoic acid $(\mathrm{C} 17: 2)$ were also identified in the tested oils, but they were present in small amounts. The contents of the first acid in all fractions were about $0.2 \%$, and the second acid about $0.05 \%$. Similar values were observed for the oils extracted using $n$-hexane and the cold-pressed oil.

The contents of various MUFA in all the extracted fractions are presented in Figure 4. The main acid of this group in the wheat germ oil was oleic acid (C18:1). In the case of the SFE-K extraction, concentrations of this acid gradually increased in the subsequent fractions from $10.5 \%$ in the first fraction to $13.6 \%$ in the middle fraction, and then remained essentially constant. During SFE-KE extraction, the oleic acid content increased in subsequent fractions from $10.8 \%$ to $14.1 \%$ in the middle fraction, and then decreased to $7.7 \%$ in the last one. Similarly, in the SFE-ME the concentration increased from 11.6 to $14.5 \%$ in the fourth fraction and dropped to $13.5 \%$ in the last one. The contents of oleic acid in the $n$-hexane-extracted oils obtained from germs from the Kupiec company and from 

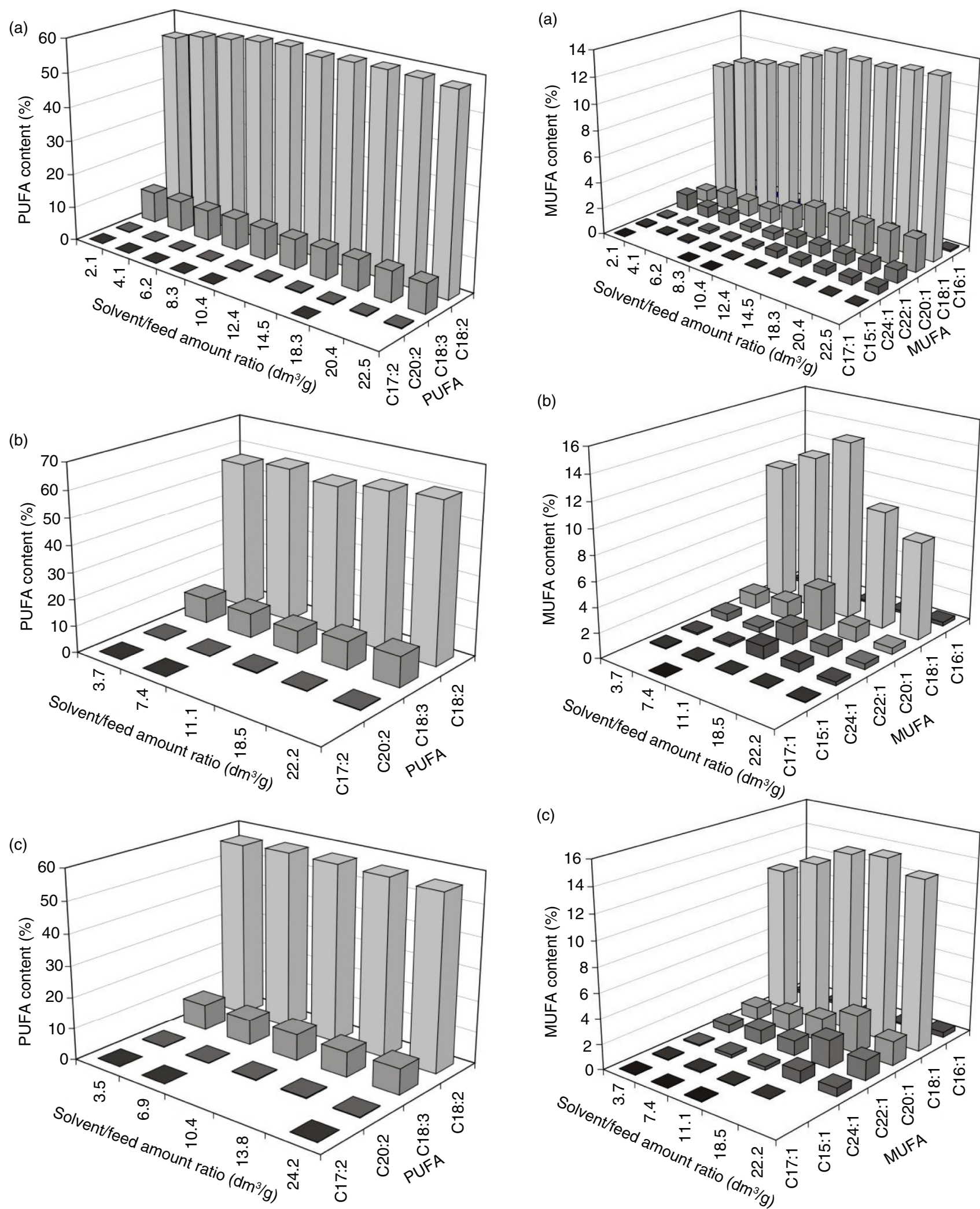

FIGURE 3. Content of various PUFA in subsequent fractions (collected after reaching specified value of solvent/feed amount ratio) of: a) SFE-K extraction, b) SFE-KE extraction, (c) SFE-ME extraction.

FIGURE 4. Content of various MUFA in subsequent fractions (collected after reaching specified value of solvent/feed amount ratio) of: a) SFE-K extraction, b) SFE-KE extraction, c) SFE-ME extraction. 
the Ciechanowiec mill were 11.5 and $12.5 \%$, respectively, and they were similar to those observed for the SFE extracts. The highest content of that acid, i.e. $19.7 \%$, was found in the cold-pressed oil.

A similar variation in the concentrations as that for oleic acid can be observed in the subsequent fractions of extracts in the case of eicosenoic acid (C20:1). However, in this case, the concentrations were significantly lower. Maximum levels were 2.5, 3.3 and $3.0 \%$ for the SFE-K, SFE-KE and SFE-ME extraction, respectively. The values found in the oils extracted with $n$-hexane were lower and amounted to 1.4 and $1.3 \%$ for the germ from the Kupiec company and Ciechanowiec mill, respectively. The coldpressed oil contained $1.1 \%$ of eicosenoic acid.

Other MUFA, such as C16:1, C22:1, C24:1, C15:1 and C17:1, were also identified in the tested oils. However, the contents of these acids were much lower than those discussed above. The total content of MUFA was the highest in the cold-pressed oil and amounted to $21.5 \%$ (Table 2), whereas it was 14.0 and $15.1 \%$ in the oils extracted by $n$-hexane for germ from the Kupiec company and Ciechanowiec mill, respectively. The content of MUFA in the SFE fractions showed similar variability to the main acids of this group. In the fractions obtained by the SFE-K, SFE-KE and SFE- ME extractions, maximum MUFA contents were observed at 17.7, 20.0 and $20.9 \%$, respectively.

SFA are mainly a source of energy, but unfortunately also cause an increase in the level of lowdensity cholesterol, and therefore a low content of SFA in oil is preferred. Wheat germ oil has a relatively low total concentration of SFA. The examined cold-pressed oil contained $16.8 \%$ SFA. The Oils extracted by $n$-hexane from germ derived from the Kupiec company and Ciechanowiec mill included a little more SFA, $18.8 \%$ and $18.4 \%$, respectively.

The results of the concentration analysis of various SFA in the fractions of oils obtained by SFE extraction are shown in Figure 5. The main SFA in the oil investigated was palmitic acid (16:0). In cold-pressed oil, its content was the lowest and amounted to $14.3 \%$. Slightly higher contents of the acid were found in oils extracted with $n$-hexane: 17.7\% (Kupiec) and 17.4\% (Ciechanowiec). The concentration of palmitic acid in the fractions of SFE extracted oils varied and depended on the time at which a particular fraction was collected and on the presence of the entrainer. In the case of SFE-K extraction, $21.9 \%$ of the acid was found in the first fraction, but this content systematically decreased in subsequent fractions to the level of about $13.5 \%$. A slightly different variation in the concentration of C16:0 acid was observed in the case of $\mathrm{CO}_{2}$ extraction with ethanol addition. A high content $(19.5 \%)$ of this acid was found in the first fractions obtained from both SFE-KE and SFE-ME and in subsequent fractions it decreased to $11.8 \%$ (SFE-KE) and
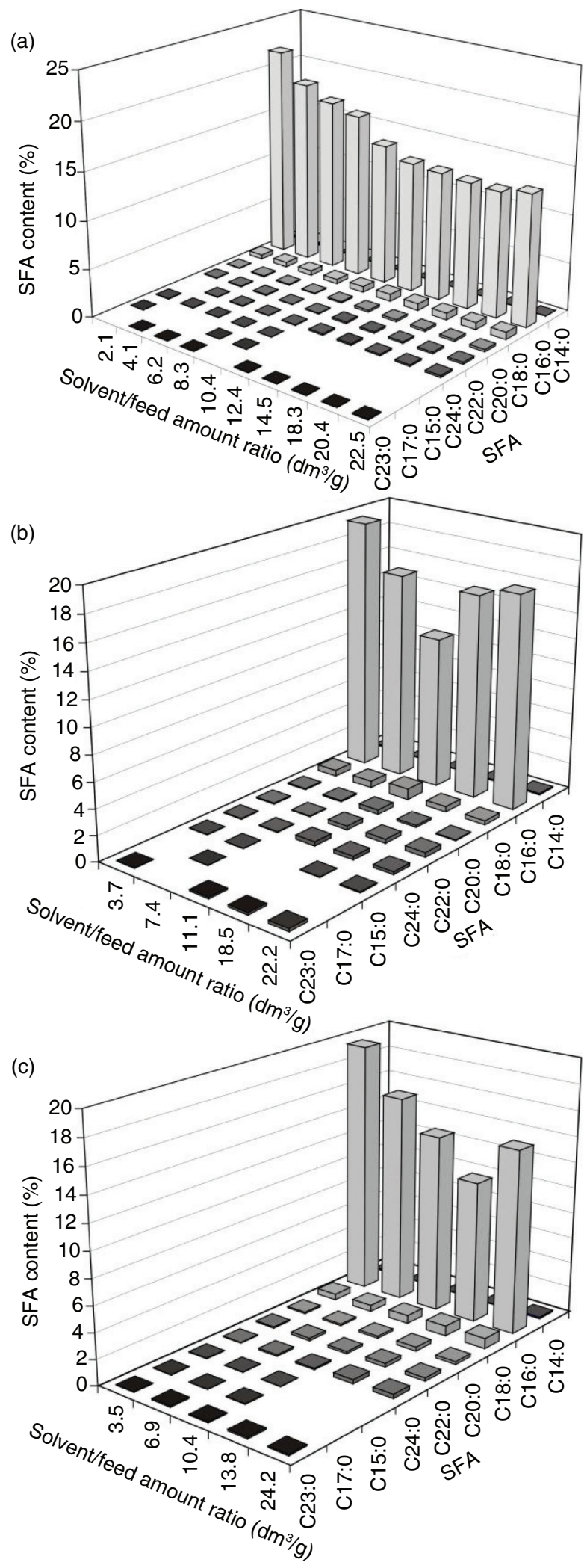

FIGURE 5. Content of various SFA in subsequent fractions (collected after reaching specified value of solvent/feed amount ratio) of: a) SFE-K extraction, b) SFE-KE extraction, c) SFE-ME extraction. 
$11.0 \%$ (SFE-ME) and then increased again. Such a relationship was mainly due to a change in the composition of the extracted MUFA and SFA and this trend was opposite to that observed for MUFA concentrations (Figure 4).

Comparing the results form Figures $4 \mathrm{~b}, \mathrm{c}$ and Figures $5 b$, c, one can notice that the selection of some fractions with a relatively high MUFA and relatively low SFA content (third for SFE-KE and fourth for SFE-ME) provide the possibility of obtaining a product with especially high nutritional value.

\section{CONCLUSIONS}

The use of ethanol as an entrainer to the supercritical $\mathrm{CO}_{2}$ extraction slightly improved the efficiency of the extraction and had practically no effect on the PUFA content in the extract. The PUFA contents in the extracts were very close to their contents in the oil obtained by $n$-hexane extraction. It was also stated that the PUFA contents were similar in all the oil fractions obtained by SFE.

The contents of SFA and MUFA in all the oils were significantly less than the PUFA contents. It was stated that average contents of MUFA and SFA in fractions of SFE extracts and their contents in the solvent extracts were similar. However, the contents of MUFA and SFA changed in subsequent fractions of oils obtained by SFE. In the middle fractions of extracts obtained with use of entrainer the maximum MUFA content and minimum PUFA content was observed.

Such variability in the fatty acid profile of consecutive fractions permits the use of fractionation in supercritical extraction to obtain more valuable oil fractions with high contents of PUFA, and higher MUFA contents than in the oil obtained without fractionation.

\section{REFERENCES}

American Oil Chemists' Society 1989. Official Methods and Recommended Practices of the American Oil Chemists' Society, 4th ed. Champaign, IL.

Bujnowski Z, Brzozowski R, Szarlik S, Cybulski J, JezierskaZięba M, Kąkol B, Dąbrowski Z, Goś A. 2011. Supercritical extraction of plant material with carbon oxide. Scaling up from laboratory to $1 / 4$ technical scale. Chemik $\mathbf{6 5}, 849-858$.

Dunford NT, Irmak S, Jonnala R. 2010. Pressurised solvent extraction of policosanol from wheat straw, germ and bran. Food Chem. 119, 1246-1249. http://dx.doi.org/10.1016/j. foodchem.2009.07.039.
Durante M, Lenucci MS, Rescio L, Mita G, Caretto S. 2012. Durum wheat by-products as natural sources of valuable nutrients. Phytochem. Rev. 11, 255-262. http://dx.doi. org/10.1007/s11101-012-9232-x.

Eisenmenger M, Dunford NT. 2008. Bioactive Components of Commercial and Supercritical Carbon Dioxide Processed Wheat Germ Oil. J. Am. Oil Chem. Soc. 85, 55-61. http:// dx.doi.org/10.1007/s11746-007-1163-0.

Ge Y, Yan H, Hui B, Ni Y, Wang S, Cai T. 2002: Extraction of Natural Vitamin E from Wheat Germ by Supercritical Carbon Dioxide. J. Agric. Food Chem. 50, 685-689.

Gelmez N, Kincal NS, Yener ME. 2009. Optimization of supercritical carbon dioxide extraction of antioxidants from roasted wheat germ based on yield, total phenolic and tocopherol contents, and antioxidant activities of the extracts. J. Supercrit. Fluids 48, 217-224. http://dx.doi. org/10.1016/j.supflu.2008.11.002.

Gomez AM, de la Ossa EM. 2000. Quality of Wheat Germ Oil Extracted by Liquid and Supercritical Carbon Dioxide. J. Am. Oil Chem. Soc. 77, 969-974. http://dx.doi.org/10.1007/ s11746-000-0153-y.

Jiang ST, Niu LY. 2011. Optimization and evaluation of wheat germ oil extracted by supercritical $\mathrm{CO}_{2}$. Grasas Aceites $\mathbf{6 2}$, 181-189. http://dx.doi.org/10.3989/gya.078710.

Jozwiak A, Brzozowski R, Bujnowski Z, Chojnacki T, Swiezewska E. 2013. Application of supercritical $\mathrm{CO}_{2}$ for extraction of polyisoprenoid alcohols and their esters from plant tissues. J. Lipid Res. 54, 2023-2028. http://dx.doi. org/10.1194/jlr.D038794.

King JW, Mohamed A, Taylor SL, Mebrahtu T, Paul C. 2001. Supercritical fluid extraction of Vernoniagalamensisseeds. Ind. Crops Prod. 14, 241-249. http://dx.doi.org/10.1016/ S0926-6690(01)00089-9.

Li H, Song Ch, Huiming ZH, Wang N, Cao D. 2011. Optimization of the Aqueous Enzymatic Extraction of Wheat Germ Oil Using Response Surface Methodology. J. Am. Oil Chem. Soc. 88, 809-817. http://dx.doi.org/10.1007/ s11746-010-1731-6.

Özcan MM, Rosa A, Dessı MA, Marongiu B, Piras A, AL-Juhaimi F.Y.I. 2013. Quality of Wheat Germ Oil Obtained by Cold Pressing and Supercritical Carbon Dioxide Extraction. Czech J. Food Sci. 31, 236-240.

Panfili G, Cinquanta L, Fratianni A, Cubadda R. 2003. Extraction of Wheat Germ Oil by Supercritical $\mathrm{CO}_{2}$ : Oil and Defatted Cake Characterization. J. Am. Oil Chem. Soc. 80, 157-161. http://dx.doi.org/10.1007/ s11746-003-0669-1.

Piras A, Rosa A, Falconieri D, Porcedda S, Dessì MA, Marongiu B. 2009. Extraction of Oil from Wheat Germ by Supercritical $\mathrm{CO}_{2}$. Molecules 14, 2573-2581. http://dx.doi. org/10.3390/molecules 14072573 .

Salgın U. 2007. Extraction of jojoba seed oil using supercritical $\mathrm{CO}_{2}+$ ethanol mixture in green and high-tech separation process. J. Supercrit. Fluids 39, 330-337. http://dx.doi. org/10.1016/j.supflu.2006.03.013.

Salgin U, Korkmaz H. 2011. A green separation process for recovery of healthy oil from pumpkin seed. $J$. Supercrit. Fluids 58, 239-248. http://dx.doi.org/10.1016/j. supflu.2011.06.002

Wang T, Johnson L. 2001. Refining High-Free Fatty Acid Wheat Germ Oil. J. Am. Oil Chem. Soc. 78, 71-76. http://dx.doi. org/10.1007/s11746-001-0222-2.

Xie M, Dunford NT, Goad C. 2011. Enzymatic Extraction of Wheat Germ Oil. J. Am. Oil Chem. Soc. 88, 2015-21. http://dx.doi.org/10.1007/s11746-011-1861-5. 